\title{
Prospective Teachers' Views on Practitioner Teacher's Attitude in Processes of Observation Made on Teaching Practice
}

\author{
Gonca Erim ${ }^{1} \&$ Alper Çetin ${ }^{2}$ \\ ${ }^{1}$ Faculty of Education, Bursa Uludağ University, Bursa, Turkey \\ ${ }^{2}$ Vocational School of Technical Science, Bursa Uludağ University, Bursa, Turkey \\ Correspondence: Gonca Erim, Faculty of Education, Bursa Uludağ University, Görükle Kampusu, 16059, Nilüfer, \\ Bursa, Turkey.
}

Received: April 15, 2020

doi:10.5539/ies.v13n8p29
Accepted: May 30, $2020 \quad$ Online Published: July 23, 2020

URL: https://doi.org/10.5539/ies.v13n8p29

\begin{abstract}
Setting as the targeting the education of individuals in terms of intellectual, perceptual and emotional aspects as a whole places the visual arts education, which is one of the fields of education, at an important position. That is due to the fact that the individual who has aesthetical perception development through fine arts education learns how to perceive new forms and to view his/her environment and artistic structures from a different perspective. Thus, the individual makes progress in his/her intellectual endeavors, and also enhances his/her creativity and builds social habits in this connection. This importance attached to visual arts education demonstrates the necessity of raising qualified visual arts teachers. The fact that teaching is a profession which is perfected through the establishment of the link between theory and practice makes worth analyzing the process of teaching practice and attitudes and guiding behaviors of practitioner teacher who is placed at the closest position to the prospective teacher in this process. In this research, the focus was placed on attitudes which practitioner teachers were supposed to demonstrate in observation processes which played a crucial role in occupational development of prospective teachers during teaching practice. These attitudes were addressed in the framework of guiding behaviors which were supposed to be beneficial to prospective teachers in observation processes.
\end{abstract}

Keywords: prospective teacher, practitioner teacher, teaching practice, visual arts education

\section{Introduction}

The society is composed of individuals who sustain themselves, have their own physical spaces, continue to exist or existed for a long time and share a lifestyle. A society which has economic, social, cultural and scientific development in a manner to comply with constantly changing and improving conditions of our age is only possible with individuals complementing it with their knowledge and skills and capable of paying respect to their environment and their own selves. That is owing to the fact that the society and individuals have a reciprocal and dynamic relationship. Hossain and Ali (2014) assert that the society cannot exist without individuals, and common efforts which are made by individuals by virtue of co-existing and acting together in groups make up the society. Also, the human being is born in a specific society and culture as an organism that is endowed with certain attributes and individualized through roles linked with that society (Gul, 2004). At this juncture, it can be suggested that the person meets his/her needs with the help of behaviors adopted from the society in which he/she is born and raised.

In this reciprocal relationship between individual and society, individuals' skills and interests are obliged to be developed in a manner to satisfy society's demands for human forces and qualifications. This is primarily reliant on education (Bal \& Basar, 2014). The most important aim of education is after all to produce the apparatus which will act to provide individuals living together with qualities, virtues, moral values and toleration competency which will contribute to the development of them and the society. These obtained values have key importance for creating a society, living together and getting civilized (Okogbaa, 2017).

Education planned in the direction of this purpose can be accepted as a system. The system is the whole set of thoughts, knowledges and teachings which are organized on the basis of a principle or view. In order to satisfy their own needs, societies develop their educational systems. A society's future can be controlled to a considerable extent only with such a system. As the existence of education connotes the existence of a societal 
environment, the socialization appertains to individual's education in its broadest sense (Gul, 2004).

\subsection{Importance of Visual Arts Education}

At present day which is called as information age, raising versatile individuals capable of meeting society's needs is possible with the delivery of a multifaceted education, and visual arts education also finds its well-deserved place in this educational approach. Qualitative knowledge obtained in the context of visual arts education is important to the development of aesthetical perception by the individual and the recognition of difference between looking and seeing, and it helps individuals achieve in being creative, entrepreneurial, problem-solver, capable of configuring, transforming and transferring available knowledge on the basis of needs. Through these competencies, the individual also shapes his/her observation skills and world of thoughts, and diversifies and develops his/her communication skills and self-expression manners.

\subsection{The Place of Teaching Practice in Teacher Education Programs}

The quality of service produced by an educational model is proportional to the quality of human resource that will run this model. This situation makes the education of teachers a topic which needs to be focused on with utmost care (Coskun, 2012). That is due to the fact that teacher's awareness about occupational responsibility influences his/her teaching skills, his/her occupational psychology and his/her student's learning performance. Definitions of teacher responsibility were identified with factors such as positive attitudes towards teaching and devotion to occupation, occupational satisfaction, positive effect on education, teachers' awareness about their impacts on students, their excitement about implementing different teaching methods and student achievements (Lauermann, 2013).

As special professional knowledge and skills are necessitated by teaching occupation, persons selecting this occupation should be equipped with certain competencies. If a good quality pre-service training is offered to prospective teachers who will execute the current educational program by getting involved in education system, then qualified individuals who will meet needs of the society in the future will also be raised. At this juncture, the key role is played by faculties of education of universities and pre-service teacher education programs which are implemented at faculties.

Pre-service teacher education programs which are applied at faculties of education are composed of two main parts, namely, theory and practice. In theoretical part of this education, prospective teachers who are students at the faculty of education attend courses which are instructed by lecturers and will enhance occupational knowledge and skills. In practical part of this education, prospective teachers acquire experience by putting theoretical knowledge and skills obtained at the faculty into practice in a real school environment through courses of School Experience and Teaching Practice.

Theory and practice interact with each other. As is known by each experienced teacher, theory disconnected from practice or practice not inspired by theory is inefficient. So much so that, teachers lacking a broad theoretical perspective fail to decide which of several teaching methods is to be used at the right moment, and get locked in the same vicious circle (Berger, 2002). That is because of the fact that teaching is a field of specialization which is perfected through theory and practice. In order to succeed in reaching goals of education, it is essential that teachers have occupational competencies at desired level. Let alone content knowledge and pedagogical formation topics, the importance of experiences in in-class processes is an issue emphasized particularly by teacher educators (Cakir, Ogan-Bekiroglu, Irez, Kahveci, \& Seker, 2010). Previous researches indicate that school practices make up the most crucial part of pre-service teacher education. That is because the establishment of a connection between theory and practice in light of knowledge base obtained by prospective teachers at the faculty is only possible if prospective teachers have the opportunity to have sufficient level of practice under the guidance of specialists prior to the service (Harmandar, Bayrakceken, Kincal, Buyukkasap, \& Kizilkaya, 2000). The course responding to this need is the course called as Teaching Practice in instruction programs of faculties of education.

Teaching Practice is a course which is modeled on faculty-school cooperation and includes activities and in-class teaching practices performed by the prospective teacher in order to obtain and develop teaching skills (Council of Higher Education of Turkey/World Bank, 1998; Bulunuz \& Gursoy, 2018). Upon the completion of the course of Teaching Practice, prospective teacher is expected to develop occupational competencies by acting as teacher in different classes at the application school and to reach a position where he/she can understand instruction programs, evaluate course books and perform measurements and evaluations in his/her own field (Council of Higher Education of Turkey/World Bank, 1998). 


\subsection{Duties and Responsibilities of Practitioner Faculty Member and Practitioner Teacher in Teaching Practice in Turkey}

In the process of teaching practice, actors directly responsible for guiding prospective teacher are practitioner faculty member and practitioner teacher. Practitioner faculty member is a lecturer of a tertiary education institution who has initial teacher training, and plans, executes and evaluates practical studies of the student to whom he/she is responsible in the process of teaching practice (Council of Higher Education of Turkey/World Bank, 1998; Bulunuz \& Gursoy, 2018). Practitioner faculty member deals with both in-class activities and academic aspect of the practice. As per Guillaume and Rudney (cited from Paker, 2008), practitioner faculty member also assumes the role of presenting theoretical knowledge for the promotion of every type of occupational development and offering alternatives to methods and techniques applied in the course. Practitioner teacher is the teacher who teaches in the same field as the prospective teacher and provides the prospective teacher with guidance and consultancy for practical studies to be performed at the school, evaluates prospective teacher's studies, helps the prospective teacher make in-class observations and works in cooperation with practitioner faculty member (Council of Higher Education of Turkey/World Bank, 1998; Bulunuz \& Gursoy, 2018). As prospective teachers spend a long time at university environment and feel responsible more towards faculty members and lecturers, they may not be well aware of the role played by practitioner teachers in teaching practice program. However, the practitioner teacher is the closest person to whom prospective teacher can always have access at the application school, whose views, recommendations and feedbacks prospective teacher can utilize, from whom prospective teacher can obtain specialist knowledge on teaching occupation and with whom prospective teacher can share experiences and thoughts (Sag, 2007).

\subsection{The Importance of Observation Processes to Teaching Practice}

Prospective teachers perform observations and practices in school environment acting as the participant observer under the guidance of experienced practitioner teachers. Especially during in-class observations, they get the chance of examining practitioner teachers' approaches to teaching processes (Cakir et al., 2010). When prospective teachers observe practitioner teachers, they obtain the opportunity to make projections for their own practices.

In-class observations made during the process of teaching practice serve as a stage in which prospective teacher gets acquainted with class dynamics by establishing bridges between worlds of theory and practice, becomes involved in documentation work and gets to know teachers' daily teaching routines (Kani \& Yilmaz, 2018). The importance of projections to be made by prospective teacher for his/her own occupational development through observations of the class and practitioner teacher demonstrates that observation processes should be carried out consciously. Moreover, practitioner teacher is obliged to establish communication with prospective teacher in a manner that will make prospective teacher feel that they are colleagues. For the development of occupational identification perceptions, prospective teachers should be recognized as teacher by students, teachers, administrative staff and other school personnel. Practitioner teacher is responsible for taking necessary steps for the implementation of this approach (Kirksekiz et al., 2015). As long as practitioner teacher succeeds in creating a healthy communication environment at workplace, prospective teacher will have no difficulty in referring to the practitioner teacher the situations, problems and questions experienced in observation processes. In the same vein, it is an established fact that healthy workplace communication will be effective in enabling practitioner teacher to listen to and understand prospective teacher and to offer guidance which will contribute to prospective teacher's occupational development in the context of observations. In raising awareness about what purposes will be served by observations to be made by prospective teacher and in understanding the importance of focusing on how practitioner teacher instructs rather than what practitioner teacher instructs, approaches of practitioner teacher become a topic which is worth analyzing.

\subsection{Objective of the Research}

In relation to the importance of observation processes carried out in the context of teaching practice, this research aimed to analyze visual arts practitioner teachers' attitudes towards and workplace communication with prospective teachers in observation process. In line with the research objective, answers to below questions were sought after:

1) What do prospective visual arts teachers think about practitioner teachers' attitudes towards in-school observations made by them in the process of teaching practice?

2) What do prospective visual arts teachers think about workplace communication which they established with practitioner teachers? 
In the framework of these two questions designed in conjunction with the research objective, attitudes and behaviors which helped the fulfillment of a successful observation process and the establishment of effective workplace communication were explained in detail, and the extent to which these attitudes and behaviors were displayed by practitioner teachers was presented.

\section{Methodology}

The research is based on data obtained from master's dissertation titled as 'Visual Arts Practitioner Teachers' Approaches to Prospective Teachers in the Process of Teaching Practice: The Case of Bursa Province, Turkey (2018). The survey model which was employed in the dissertation is also applicable to this research.

\subsection{Data Collection Tool}

For the survey model which was implemented for defining cases, objects and individuals as they actually were without imposing any experimental intervention on them, a 3-point Likert-type survey was prepared. This research covers the two parts of the survey which were composed of a total of five parts. These parts named as part A and part B. The part A of the survey focuses on practitioner teachers' attitudes to in-school observation processes of prospective visual arts teachers, whereas the part B of the survey places the focus on workplace communication established by visual arts practitioner teachers with prospective teachers.

The survey form was applied to 57 students who took the course of Teaching Practice and were enrolled in spring semester of the academic year of 2017-2018 at Art Teaching Program of Fine Arts Education Department of Uludag University, Bursa, Turkey. Findings were reported on the basis of frequencies and percentages of data acquired through survey forms, and qualitative comments were made with the help of relevant literature.

\subsection{Population and Sample}

Research population was composed of students who took the course of Teaching Practice and were enrolled at Art Teaching Programs of Fine Arts Education Departments of Faculties of Education of Turkish Universities. The research was conducted within Bursa Province of Turkey, and the sample representing the population was comprised of 57 students who took the course of Teaching Practice and were enrolled in spring semester of the academic year of 2017-2018 at Art Teaching Program of Fine Arts Education Department of Uludag University. 57 participant students performed the process of teaching practice under the guidance of a total of 13 practitioner teachers employed at five different elementary schools within Bursa Province. The sample was selected through convenience sampling method.

\section{Findings and Comments}

The part A of the survey covers the first question of this research, that is, attitudes supposed to be demonstrated by practitioner teachers towards in-school observations made by prospective visual arts teachers in the process of teaching practice. This attitude was addressed in the context of 10 guiding behaviors supposed to be performed by visual arts practitioner teachers towards prospective teachers. These 10 guiding behaviors were formed on the basis of the review of domestic and foreign teaching practice literature which was relevant to the research question. Views, comments, recommendations in the literature and common statements encountered in scales were grouped and utilized in the identification of desired guiding behaviors. Of the options of 'I agree', 'Neither agree nor disagree', 'I disagree', prospective visual arts teachers selected the option they deemed the most proper in order to indicate whether these behaviors were performed by practitioner teachers. In Table 1, findings on 10 propositions which make up the part A are exhibited:

Table 1. Attitudes demonstrated by practitioner teachers towards in-school observations made by prospective visual arts teachers

\begin{tabular}{|c|c|c|c|c|c|c|c|c|c|}
\hline \multirow[t]{2}{*}{ Propositions } & & \multicolumn{2}{|c|}{ I agree } & \multicolumn{2}{|c|}{$\begin{array}{l}\text { Neither agree nor } \\
\text { disagree }\end{array}$} & \multicolumn{2}{|c|}{ I disagree } & \multicolumn{2}{|c|}{ Total } \\
\hline & & $\mathrm{f}$ & $\%$ & $\mathrm{f}$ & $\%$ & $\mathrm{f}$ & $\%$ & $\mathrm{f}$ & $\%$ \\
\hline Proposition 1 & $\begin{array}{l}\text { The practitioner teacher } \\
\text { informed me about the } \\
\text { socio-economic condition of } \\
\text { the application school. }\end{array}$ & 28 & 49.12 & 15 & 26.32 & 14 & 24.56 & 57 & 100 \\
\hline
\end{tabular}




\begin{tabular}{|c|c|c|c|c|c|c|c|c|c|}
\hline Proposition 2 & $\begin{array}{l}\text { The practitioner teacher } \\
\text { informed me about the social } \\
\text { dynamics of classes (class } \\
\text { atmosphere, communication } \\
\text { of students at individual level } \\
\text { and so on.) whose courses we } \\
\text { attended. }\end{array}$ & 38 & 66.67 & 14 & 24.56 & 5 & 8.77 & 57 & 100 \\
\hline Proposition 3 & $\begin{array}{l}\text { The practitioner teacher } \\
\text { informed me about targeted } \\
\text { achievements which lied at } \\
\text { the heart of activities the } \\
\text { students were asked to } \\
\text { perform in visual arts } \\
\text { courses. }\end{array}$ & 39 & 68.42 & 11 & 19.3 & 7 & 12.28 & 57 & 100 \\
\hline Proposition 4 & $\begin{array}{l}\text { The practitioner teacher } \\
\text { explained to me the reasons } \\
\text { for selecting teaching } \\
\text { methods which he/she used } \\
\text { in visual arts courses. }\end{array}$ & 31 & 54.39 & 20 & 35.09 & 6 & 10.52 & 57 & 100 \\
\hline Proposition 5 & $\begin{array}{l}\text { The practitioner teacher } \\
\text { informed me about teaching } \\
\text { materials which he/she used } \\
\text { or developed in visual arts } \\
\text { courses. }\end{array}$ & 40 & 70.18 & 12 & 21.05 & 5 & 8.77 & 57 & 100 \\
\hline Proposition 6 & $\begin{array}{l}\text { The practitioner teacher } \\
\text { provided me information as } \\
\text { to where and how he/she } \\
\text { applied classroom } \\
\text { management models. }\end{array}$ & 34 & 59.65 & 15 & 26.30 & 8 & 14.05 & 57 & 100 \\
\hline Proposition 7 & $\begin{array}{l}\text { The practitioner teacher } \\
\text { informed me about methods } \\
\text { used for motivating students } \\
\text { and allowed me to observe } \\
\text { them during lectures }\end{array}$ & 39 & 68.42 & 14 & 24.56 & 4 & 7.02 & 57 & 100 \\
\hline Proposition 8 & $\begin{array}{l}\text { While I was observing the } \\
\text { lecture, the practitioner } \\
\text { teacher gave me his/her own } \\
\text { lecture plan and enabled me } \\
\text { to make observations via this } \\
\text { plan during the lecture. }\end{array}$ & 34 & 59.65 & 10 & 17.54 & 13 & 22.81 & 57 & 100 \\
\hline Proposition 9 & $\begin{array}{l}\text { The practitioner teacher gave } \\
\text { me duties and responsibilities } \\
\text { so that I could play an active } \\
\text { role as the participant } \\
\text { observer. }\end{array}$ & 48 & 84.21 & 8 & 14.04 & 1 & 1.75 & 57 & 100 \\
\hline Proposition 10 & $\begin{array}{l}\text { On the basis of negative } \\
\text { conditions or shortcomings at } \\
\text { the application school, the } \\
\text { practitioner teacher gave me } \\
\text { illustrative examples to help } \\
\text { me tackle such negative } \\
\text { conditions and shortcomings. }\end{array}$ & 38 & 66.68 & 16 & 28.07 & 3 & 5.25 & 57 & 100 \\
\hline
\end{tabular}

$\mathrm{N}=57$.

For the first proposition of the part A of the survey which asserted that "The practitioner teacher informed me 
about the socio-economic condition of the application school.", 28 (49.12\%) of all 57 participants selected the option of 'I agree' whereas 15 participants (26.32\%) selected the option of 'Neither agree nor disagree' and 14 participants $(24.56 \%)$ selected the option of 'I disagree'.

There is direct association between the economic condition of a school and students' academic achievements and their perspectives on courses. For instance, legal guardians of students who are enrolled at a school with low socio-economic level can be more reluctant to prepare their children for courses. This situation can have negative implications on students' sense of preparedness and perspectives on courses (Donmez, Ugurlu, \& Comert, 2011). Visual arts education is a field of study, the value of which was not sufficiently appreciated yet in today's Turkey. Legal guardians of students and students themselves can have prejudices against this course. Materials necessary for carrying out this course can also make an economic problem for certain families. All these factors should be taken into consideration in the identification of ways and approaches to be adopted in the application process of visual arts course. Information to be offered by visual arts practitioner teachers to the prospective teacher about the socio-economic condition of the school will help the prospective teacher observe students and teacher in educational process in a more conscious manner. The fact that the selection frequency of the option of 'I agree' is the lowest in this proposition(49.12\%) as compared to all other propositions in this part indicates that almost half of visual arts practitioner teachers should provide information and guidance about socio-economic condition of the school in a more conscious manner.

For the second proposition which suggested that "The practitioner teacher informed me about the social dynamics of classes (class atmosphere, communication of students at individual level and so on.) whose courses we attended.", $38(66.67 \%)$ of all 57 participants selected the option of 'I agree' whereas 14 participants $(24.56 \%)$ selected the option of 'Neither agree nor disagree' and 5 participants $(8.77 \%)$ selected the option of 'I disagree'.

Each student in a class comes from a different family structure, culture or environment. This situation implies that they have different levels of social development and so they are endowed with distinct communication features. Students will reflect these differences on class environment through their behaviors and will affect the class atmosphere. That is by virtue of the fact that the class atmosphere is a social environment which has uniquely particular attributes, and in which learning and teaching activities are carried out and students and teacher communicate with each other (Ekici, 2018). That practitioner teacher gives information on students' individual communication features and class atmosphere enables that prospective teachers can observe how the practitioner teacher benefits from being familiar with these communication features and class atmosphere while getting involved in teaching processes. The prospective teacher who understands what different class atmospheres and individual features mean to an experienced teacher and how the experienced teacher reflects this input on teaching processes will also benefit from these inputs in his/her own practices. On the basis of the quantitative findings, it is ascertained that most prospective visual arts teachers $(66.67 \%)$ find that the guidance provided by practitioner teachers on this matter is satisfactory.

For the third proposition which stated that "The practitioner teacher informed me about targeted achievements which lied at the heart of activities the students were asked to perform in visual arts courses.", $39(68.42 \%)$ of all 57 participants selected the option of 'I agree' whereas 11 participants (19.3\%) selected the option of 'Neither agree nor disagree' and 7 participants (12.28\%) selected the option of 'I disagree'.

Just as in the case of other courses, the instruction plan of visual arts course also aims to obtain certain achievements. Through planned activities and experiences, achievements of education serve to create behavioral changes demanded from individuals (Sonmez, 2010). Therefore, activities performed by visual arts teacher in relation to the course topic are intended for ensuring that students obtain achievements which are specified on instruction plan. In a general sense, prospective teachers also note that, in designing activities related to targeted achievements, they feel the need to analyze activities of practitioner teachers (Kirksekiz, Uysal, Isbulan, Akgun, Kiyici, \& Horzum, 2015). For that reason, visual arts practitioner teachers should always inform prospective teachers about targeted achievements and activities which they asked students to perform. With regards to the quantitative findings, it is discerned that most prospective visual arts teachers $(68.42 \%)$ find that the information and guidance provided by practitioner teachers on targeted achievements are sufficient.

For the fourth proposition which remarked that "The practitioner teacher explained to me the reasons for selecting teaching methods which he/she used in visual arts courses.", 31 (54.39\%) of all 57 participants selected the option of 'I agree' whereas 20 participants (35.09\%) selected the option of 'Neither agree nor disagree' and 6 participants (10.52\%) selected the option of 'I disagree'.

In enabling students to reach targeted achievements of a course, ensuring the permanency of learning of the 
information delivered to students and helping the intellectual and physical developments of students to advance in the desired direction, teaching methods applied by teachers occupy a crucial place (Cal, 2016).Along with the fact that visual arts course, a course which plays a role in raising creative individuals, brings observations, authenticity, discovery and personal approaches together, the choice of teaching methods and techniques becomes a topic with critical importance to ensuring that student gets the maximum benefit from this course (Yolcu, 2004). This is due to the fact that there are no clear-cut practices in arts education vis-à-vis other fields. Practices executed in arts education are shaped by differences and emotions of persons who receive the education. This situation makes it impossible to have just one single method comprehensive enough to address each individual. Both in theoretical education and workshop practices, the importance of teaching methods and techniques is a topic on which visual arts practitioner teachers should focus. In the context of their occupational experiences, visual arts practitioner teachers should provide the prospective teacher with information as to which teaching methods are applied to which situations. Otherwise, prospective teacher will be challenged in making sense of the philosophy and reasons behind teaching methods selected by practitioner teacher. Prospective teachers also assert that they expect to receive from practitioner teachers the guidance as to when and how teaching methods can be utilized (Chitpin, 2011). With respect to the quantitative findings, it is perceived that more than half of prospective visual arts teachers (54.39\%) find that the information and guidance offered by practitioner teachers about teaching methods are adequate.

For the fifth proposition which put forward that "The practitioner teacher informed me about teaching materials which he/she used or developed in visual arts courses.", 40 (70.18\%) of all 57 participants selected the option of 'I agree' whereas 17 participants (21.05\%) selected the option of 'Neither agree nor disagree' and 5 participants $(8.77 \%)$ selected the option of 'I disagree'.

Concepts and practices making up the content of visual arts course can be composed of matters which are hard to materialize in mind. If attempts are made to transfer these challenging matters to students through teaching materials capable of attracting the attention from multiple sensory organs, then the permanency of learning can be more easily attained. Even if a visual arts teacher offers just visual illustrations about information which is presented to students and the corresponding activities which are performed with students, students will have positive results in reaching targeted achievements. A teaching material capable of attracting attention from most sensory organs makes the learning process even more entertaining, instructive, simple and interesting for students (Yilmaz \& Bilici, 2016). For example, a research performed in Texas, the USA, revealed that human beings achieved in learning $10 \%$ of what they read, $20 \%$ of what they heard, $30 \%$ of what they saw, $50 \%$ of what they saw and heard, $80 \%$ of what they saw, heard and told, and $90 \%$ of what they saw, heard, touched and told (Kinder, 1973). That is why, visual arts practitioner teachers should provide prospective teachers under their guidance with information on teaching materials which they used or developed. Information to be given as to which teaching materials are utilized by visual arts practitioner teachers under what circumstances provides prospective teachers with the opportunity to observe how students react to these materials in the learning process. The analysis of efficacies of visual arts teachers to use or develop teaching materials as response to the satisfaction of needs is the topic of another research. In view of the quantitative findings, it is viewed that a large majority of prospective visual arts teachers $(70.18 \%)$ find that the information and guidance offered by practitioner teachers about teaching materials are satisfactory.

For the sixth proposition which suggested that "The practitioner teacher provided me information as to where and how he/she applied classroom management models", 34 (59.64\%) of all 57 participants selected the option of 'I agree' whereas 15 participants (26.32\%) selected the option of 'Neither agree nor disagree' and 8 participants (14.04\%) selected the option of 'I disagree'.

Intended for creating a positive class atmosphere which will buttress the education process, the classroom management is a process with different aspects such as specifying rules to be followed in the classroom, making physical arrangements, managing time and teaching processes and controlling student behaviors (Sevce, 2017). Visual arts course is practice-oriented due to its content, and requires students to work individually or in groups within a workshop environment. This requirement induces visual arts teachers to make plans with respect to physical arrangement, effective communication, behavioral management, time and instruction aspects of the classroom or workshop. The selection of classroom management models is associated with students' needs and personal features, physical conditions and teachers' personal attributes. A prospective visual arts teacher endeavoring to have occupational development is in need of supervision and guidance for obtaining information as to which of several classroom management models are supposed to be applied under what circumstances. At this juncture, practitioner teacher should provide the prospective teacher with necessary information on models applied by himself/herself and clear the way for the prospective teacher to make observations of himself/herself 
in a conscious manner during the course. On the basis of the quantitative findings, it is seen that more than half of prospective visual arts teachers (59.64\%) were informed about classroom management methods used by practitioner teachers.

For the seventh proposition which asserted that "The practitioner teacher informed me about methods used for motivating students and allowed me to observe them during lectures.", 39 (68.42\%) of all 57 participants selected the option of 'I agree' whereas 14 participants (24.56\%) selected the option of 'Neither agree nor disagree' and 4 participants (7.02\%) selected the option of 'I disagree'.

Brown (2001) defines the motivation as the condition of cognitive and perceptual awakening which induces a person to take action for reaching a specific target. In order to assure that the learning is realized and students adopt the desired behavioral changes, teachers apply motivating methods such as giving presents, praising and providing positive feedback. That is owing to the fact that, if students are not motivated to learn at the desired level, even students with superior skills and intrinsic motivation can gradually lose their enthusiasm to reach long-term goals. Especially students with low interest and intrinsic motivation for visual arts course need to have extrinsic motivation. On the basis of this importance attached to motivation, visual arts practitioner teachers should inform prospective teachers about methods applied to motivate students in teaching processes. Thus, prospective visual arts teacher will both develop his/her theoretical knowledge base and make more productive observations. With regards to the quantitative findings, it is observed that the majority of prospective visual arts teachers $(68.42 \%)$ find that the guidance offered by practitioner teachers about motivating methods is sufficient.

For the eighth proposition which stated that "While I was observing the lecture, the practitioner teacher gave me his/her own lecture plan and enabled me to make observations via this plan during the lecture.", 34 (59.65\%) of all 57 participants selected the option of 'I agree' whereas 10 participants $(17.54 \%)$ selected the option of 'Neither agree nor disagree' and 13 participants (22.81\%) selected the option of 'I disagree'.

That the practitioner teacher gives his/her lecture plan to the prospective teacher for examination and enables the practitioner teacher to make observations in this respect is not a responsibility clearly defined as per current teaching approaches to practical application. Still, the fact that the practitioner teacher takes initiative and adopts such an approach suggests that the prospective teacher receives guidance for lecture plans which he/she will prepare later and observe how a lecture plan is implemented in teaching processes on a one-on-one basis. On the other hand, prospective teachers themselves express their needs for analyzing practitioner teachers' lecture plans (Paker, 2008). That is why, the fact that more than half of research participants $(59.65 \%)$ were faced with such a guidance behavior implies a positive result.

For the ninth proposition which set forth that "The practitioner teacher gave me duties and responsibilities so that I could play an active role as the participant observer.", 48 (84.21\%) of all 57 participants selected the option of 'I agree' whereas 8 participants (14.04\%) selected the option of 'Neither agree nor disagree' and 1 participant $(1.75 \%)$ selected the option of 'I disagree'.

Upon the review of literature on teaching practice, the fact that prospective teachers assert that constantly performing observation-based activities makes them passive learners and so a more balanced approach in which they will be more active during in-class observations is necessary captures attention (Ogan-Bekiroglu, Kahveci, Irez, Seker, \& Cakir, 2010).

That the option of 'I agree' had the highest selection frequency in this proposition indicates that a large majority of prospective teachers enrolled at Arts Teaching Program of the Faculty of Education of Uludag University (84.21\%) find that practitioner teachers' attitude is satisfactory for prospective teachers to assume an active role in observation processes of teaching practice.

For the tenth proposition of the part A of the survey which put forward that "On the basis of negative conditions or shortcomings at the application school, the practitioner teacher gave me illustrative examples to help me tackle such negative conditions and shortcomings.", 38 (66.68\%) of all 57 participants selected the option of 'I agree' whereas 16 participants (28.08\%) selected the option of 'Neither agree nor disagree' and 3 participants $(5.25 \%)$ selected the option of 'I disagree'.

Problems arising from the lack of a workshop to be used in performing visual arts course at certain schools have effects on the ways visual arts teachers handle the lecture. For the purpose of removing the influence of available negative conditions and shortcomings on teaching processes, visual arts teachers can be urged to take steps to develop materials and to plan activities. Therefore, it is important that a visual arts teacher just starting his/her career previously have a debate as to how to respond to negative conditions and shortcomings under the guidance of practitioner teachers. In view of the quantitative findings, it is discerned that the majority of 
prospective visual arts teachers $(66.68 \%)$ find that the guidance offered by practitioner teachers on this topic is sufficient.

In the part A of the survey, all propositions except for the first proposition demonstrate that more than half of prospective visual arts teachers find that practitioner teachers' guiding behaviors during observation processes were satisfactory. Even if findings are positive in terms of quantitative results, it is an established fact that guiding behaviors performed by visual arts practitioner teachers in observation processes are open to further development and also need to be developed. For instance, the option of 'I agree' had the lowest selection frequency in the first proposition of the part A which stated that "The practitioner teacher informed me about the socio-economic condition of the application school". Even if 28 of all 57 research participants selected the option of 'I agree', the remaining 29 participants selected the options of 'Neither agree nor disagree' or 'I disagree'. When evaluated solely quantitatively, these results can be deemed as moderately successful. However, it is likely that these 29 students had trouble in elucidating that information on socio-economic condition of the school had what type of an impact on and importance to the planning of teaching processes. When prospective teachers launch their careers, it is not desirable that prospective teachers plan and execute teaching processes by neglecting these issues until they finally get enough experience. The fact that even a single prospective teacher is responsible for lecturing visual arts to tens of students in the first year of his/her occupation must always be born in mind. This situation indicates that even the most positive findings to be obtained quantitatively may not necessarily offer any favorable return in real life.

The part B of the survey covers the second question of this research, that is, workplace communication established by visual arts practitioner teachers with prospective teachers. In Table 2, findings on 6 propositions which make up the part B are exhibited:

Table 2. Workplace communication established by visual arts practitioner teachers with prospective teachers

\begin{tabular}{|c|c|c|c|c|c|c|c|c|c|}
\hline \multirow[t]{2}{*}{ Propositions } & & \multicolumn{2}{|c|}{ I agree } & \multicolumn{2}{|c|}{$\begin{array}{c}\text { Neither agree nor } \\
\text { disagree }\end{array}$} & \multicolumn{2}{|c|}{ I disagree } & \multicolumn{2}{|c|}{ Total } \\
\hline & & $\mathrm{f}$ & $\%$ & $\mathrm{f}$ & $\%$ & $\mathrm{f}$ & $\%$ & $\mathrm{f}$ & $\%$ \\
\hline Proposition1 & $\begin{array}{l}\text { Throughout the teaching } \\
\text { practice, the practitioner } \\
\text { teacher was prepared and } \\
\text { eager to assume the role of a } \\
\text { guide and advisor. }\end{array}$ & 43 & 75.45 & 12 & 21.05 & 2 & 3.50 & 57 & 100 \\
\hline Proposition 2 & $\begin{array}{l}\text { The practitioner teacher } \\
\text { provided me with a } \\
\text { communication opportunity } \\
\text { through which I could } \\
\text { express myself freely in and } \\
\text { out of the classroom. }\end{array}$ & 46 & 80.7 & 10 & 17.55 & 1 & 1.75 & 57 & 100 \\
\hline Proposition3 & $\begin{array}{l}\text { The practitioner teacher } \\
\text { continued to have } \\
\text { communication with me as a } \\
\text { colleague during breaks } \\
\text { between lectures. }\end{array}$ & 50 & 87.75 & 5 & 8.75 & 2 & 3.50 & 57 & 100 \\
\hline $\begin{array}{l}\text { Propositio } \\
4\end{array}$ & $\begin{array}{l}\text { The practitioner teacher was } \\
\text { tolerant of my mistakes } \\
\text { during the teaching practice. }\end{array}$ & 46 & 80.7 & 11 & 19.3 & 0 & 0 & 57 & 100 \\
\hline Proposition5 & $\begin{array}{l}\text { The practitioner teacher } \\
\text { helped me maintain my } \\
\text { motivation by encouraging } \\
\text { me at each stage of the } \\
\text { process of teaching practice. }\end{array}$ & 45 & 78.95 & 7 & 12.28 & 5 & 8.77 & 57 & 100 \\
\hline
\end{tabular}




\begin{tabular}{|c|c|c|c|c|c|c|c|c|c|}
\hline Proposition 6 & $\begin{array}{l}\text { The practitioner teacher } \\
\text { became a very good listener } \\
\text { with whom I could } \\
\text { comfortably share my } \\
\text { problems and observations }\end{array}$ & 45 & 78.95 & 11 & 19.3 & 1 & 1.75 & 57 & 100 \\
\hline
\end{tabular}

$\mathrm{n}=57$.

For the first proposition of the part B of the survey which suggested that "Throughout the teaching practice, the practitioner teacher was prepared and eager to assume the role of a guide and advisor.", $43(75.45 \%)$ of all 57 participants selected the option of 'I agree' whereas 12 participants $(21.05 \%)$ selected the option of 'Neither agree nor disagree' and 2 participants (3.50\%) selected the option of 'I disagree'. The individual should firstly designate his/her own position in order to ensure that he/she complies with the environment he/she occupies. Thus, departing from his/her own position, he/she can administer his/her relations with phenomena, cases, situations, objects and other individuals in his/her external environment, and can define his place and accordingly the roles and functions which he/she needs to assume. An individual who embraced his own position and duties will approach phenomena, cases, situations, objects or individuals in his/her environment with this understanding. $\mathrm{He} / \mathrm{she}$ will be able to navigate his/her relations in the desired direction with individuals with which he/she shares a common vision (Inceoglu, 2010). If the practitioner teacher also has a positive way of thinking towards his/her role in the process of teaching practice and towards the prospective teacher, he/she will be prepared to behave in a manner required by this process. On account of these reasons, it is important that teachers assigned with the responsibility of being the practitioner teacher be keen on assuming all their responsibilities without seeing these roles as workload. In light of the quantitative findings, it can be argued that a large majority of prospective visual arts teachers $(75.45 \%)$ find that practitioner teachers are eager and prepared to assume the role of guide and advisor.

After presenting quantitative findings on the second, third, fourth, fifth and sixth propositions of the part B of the survey, a common comment was provided owing to the relationship of these propositions with the right manner of workplace communication.

For the second proposition which set forth that "The practitioner teacher provided me with a communication opportunity through which I could express myself freely in and out of the classroom.", 46 (80.7\%) of all 57 participants selected the option of 'I agree' whereas 10 participants (17.55\%) selected the option of 'Neither agree nor disagree' and 1 participant (1.75\%) selected the option of 'I disagree'.

For the third proposition which hinted that "The practitioner teacher continued to have communication with me as a colleague during breaks between lectures." $50(87.75 \%)$ of all 57 participants selected the option of 'I agree' whereas 5 participants $(8.75 \%)$ selected the option of 'Neither agree nor disagree' and 2 participants $(3.50 \%)$ selected the option of 'I disagree'.

For the fourth proposition which put forward that "The practitioner teacher was tolerant of my mistakes during the teaching practice." $46(80.7 \%)$ of all 57 participants selected the option of 'I agree' whereas 11 participants (19.3\%) selected the option of 'Neither agree nor disagree' and no participant selected the option of 'I disagree'.

For the fifth proposition which asserted that "The practitioner teacher helped me maintain my motivation by encouraging me at each stage of the process of teaching practice.", 45 (78.95\%) of all 57 participants selected the option of 'I agree' whereas 7 participants (12.28\%) selected the option of 'Neither agree nor disagree' and 5 participants $(8.77 \%)$ selected the option of 'I disagree'.

For the sixth proposition of the fifth part of the survey which set forth that "The practitioner teacher became a very good listener with whom I could comfortably share my problems and observations.", 45 (78.95\%) of all 57 participants selected the option of 'I agree' whereas 11 participants (19.3\%) selected the option of 'Neither agree nor disagree' and 1 participant (1.75\%) selected the option of 'I disagree'.

That practitioner teachers have willingness and attachment to the education of adults and can have success in having communication with them is of importance (Izadinia, 2017). An experienced practitioner teacher creates an atmosphere of reciprocal dialog with prospective teachers by listening to them. The practitioner teacher makes efforts to avoid having unilateral communication. This open communication atmosphere offers the possibility to the prospective teacher to express himself/herself more clearly (Boreen, 2009). A communication established through questions and answers will enable the practitioner teacher to transfer pedagogical and practical knowledge to the prospective teacher by benefiting from a more clear analysis of needs of the prospective 
teacher. Inputs obtained through the right form of communication in the process of teaching practice will clear the way for the encouragement of prospective teacher at the right point and at the right time in order to enhance and maintain prospective teacher's motivation. The fact that the option of 'I agree' was selected by $80.7 \%$ of participants for the second proposition, by $87.75 \%$ of participants for the third proposition, by $80.7 \%$ of participants for the fourth proposition, by $78.95 \%$ of participants for the fifth proposition and by $78.95 \%$ of participants for the sixth proposition demonstrates that a large majority of prospective visual arts teachers find that practitioner teachers' workplace communication is satisfactory.

\section{Results}

Table 3 was created to display a quantitative overview of the part A and the part B of the survey. In each part, arithmetic means of frequencies and percentage distributions of propositions were taken into account and a general picture was presented.

Table 3. Arithmetic means of frequencies and percentage distributions of propositions of Part A and Part B

\begin{tabular}{ccccccccc}
\hline Parts & \multicolumn{2}{c}{ I agree } & \multicolumn{2}{c}{ Neither agree Nor disagree } & \multicolumn{2}{c}{ I disagree } & \multicolumn{2}{c}{ Total } \\
\hline & $\mathrm{f}$ & $\%$ & $\mathrm{f}$ & $\%$ & $\mathrm{f}$ & $\%$ & $\mathrm{f}$ & $\%$ \\
\hline PartA & 37 & 64.91 & 13 & 22.81 & 7 & 12.28 & 57 & 100 \\
\hline PartB & 46 & 80.7 & 9 & 15.8 & 2 & 3.5 & 57 & 100 \\
\hline
\end{tabular}

$\mathrm{n}=57$.

When practitioner teachers' attitudes and guiding behaviors during the process of in-school observation by prospective teachers are addressed in detail, findings show that more than half of prospective teachers expressed positive views. Even if the selection frequency of the option of 'I agree' which is $64.91 \%$ shows up a majority quantitatively, the fact that the guiding behaviors defined in propositions prepared in a comprehensive way to make observation process ideal are not $35.09 \%$ satisfactory should not be neglected. The assessment of this result is not supposed to be focused solely on the practitioner teacher, but the probability that prospective teachers' demand for or awareness about such guiding behaviors does not exist should also be taken into consideration.

When quantitative findings of the part B of the survey are examined in this sense, a large majority of prospective teachers who are enrolled at Arts Education Program of the Faculty of Education of Uludag University rate positively the workplace communication established with practitioner teachers in the process of teaching practice.

\section{Discussion and Recommendations}

Findings on the part B of the survey covered by the research indicate that prospective teachers who are enrolled at Arts Education Program of the Faculty of Education of Uludag University find that visual arts practitioner teachers are proficient in workplace communication. However, it is discerned that there is a quantitative fall in findings on observation processes. Even though both practitioner teachers and prospective teachers try to fulfill their duties in the context of Faculty-School Cooperation program, it can be asserted that the obligation of both sides to express their duties, expectations and needs with more clear descriptions arise when a multi-dimensional aspect of education, instruction and learning processes is taken into consideration. The awareness about this obligation can lead the practitioner teacher to create a tangible responsibility content by specifying which situations, cases and processes in school and classroom atmosphere should be observed and experienced by prospective teachers, and which and how class management and instruction methods will be observed by prospective teachers.

As of 2018, the process of teaching practice was regularly monitored by MEBBIS (Information Systems of Ministry of National Education of Turkey). Each prospective teacher is registered to the system by the deputy school principal who is in charge of practice. Practitioner teachers are responsible for entering prospective teachers' attendance \& absence records and submitting written assessment reports on their in-class observations and class lectures into MEBBIS. Practitioner faculty members are responsible for making evaluations on what they listened during class lectures delivered by the prospective teachers and submitting the final evaluation. In the process of teaching practice, practitioner teacher and practitioner faculty member are obliged to provide the prospective teacher with constant flow of feedbacks. It can be thought that the increase in communication and control in this direction naturally enhances attachment to the institution. However, in order to reveal to what 
extent practitioner teacher's attitudes and behaviors are modified after this change in the system, analogous researches can be conducted in provinces across different regions of Turkey. Seminars organized by Provincial Directorates of the Ministry of National Education of Turkey for practitioner teachers in recent years can be repeated every year and teachers who participated in these seminars in the past can attend them once again.

\section{References}

Bal, B., \& Basar, E. (2014). Finlandiya, Almanya, Singapur ve Türkiye'nin eğitim sistemleri açısından kademeler arası geçiş sistemlerinin karşılaştırılması. Çukurova Üniversitesi Türkoloji. Retrieved from http://turkoloji.cu.edu.tr/pdf/belgin_bal_erdogan_basar_kademeler_arasi_gecis_sistemi.pdf

Berger, K. S. (2002). Theory and practice: Teaching in the real world. Toughand Action, 17(2), 107-116. Retrieved from http://www.nea.org/assets/img/PubThoughtAndAction/TAA_01Win_12.pdf

Boreen, J. (Ed.). (2009). Mentoring beginning teachers: Guiding, refleceting, coaching. Portshmouth: Stenhouse Publishers.

Brown, D. (2001). Using instructional media. New York: Longman.

Bulunuz, N., \& Gursoy, E. (Eds). (2018). Klinik danismanlik modeli iyi öğretmenlik uygulamalari kilavuzu. Ankara: Ani Publishing.

Cakir, M., Ogan-Bekiroglu, F., Irez, S., Kahveci, A., \& Seker, H. (2010). Fakülte-okul işbirliği modelinin değerlendirilmesi: Uygulama öğretmenlerinin görüşleri. Marmara University Atatürk Education Faculty Journal of Educational Sciences, 31, 69-81. Retrieved from http://dergipark.org.tr/tr/pub/maruaebd/issue/354/2551

Cal, E. (2016). Ortaokul matematik ögrretmenlerinin ögretim yöntemlerine karşı düşünce ve önerilerinin değerlendirilmesi (Unpublished master's thesis). Ataturk University, Erzurum.

Chitpin, S. (2011). Can mentoring and reflection cause change in teaching practice? A Professional development journey of a Canadian teacher educator. Professional Development in Education, 37(2), 225-240. https://doi.org/10.1080/19415257.2010.531625

Coskun, C. (2012). Öğretmen adaylarının uygulama ögretmenliği yeterliliklerine ilişkingörüşleri (Aydın ili örneği) (Unpublished master's thesis). Adnan Menderes University, Aydin.

Council of Higher Education of Turkey/World Bank. (1998). Fakulte-okul isbirligi. Retrieved from http://www.yok.gov.tr/documents/10279/23817636/fakulte_okul_isbirligi.pdf

Donmez, B., Ugurlu, C., \& Comert, M. (2011). Desicion-making, leadership and conflict in primary schools as loosely coupled system. Uludag University Journal of Faculty of Education, 24(1), 1-29. Retrieved from https://dergipark.org.tr/en/pub/uefad/issue/16693/173504

Ekici, E., (2018). Türkçe öğretim merkezlerinde görev yapan öğretim elemanlarının olumlu sınıf iklimi sağlama yeterliliklerinin incelenmesi (Unpublished master's thesis). Ahi Evran University, Kirsehir.

Gul, G. (2004). Birey, toplum, egitim ve oğretmen. HAYEF: Journal of Education, 1, 223-236. Retrieved from https://hayefjournal.org/tr/birey-toplum-egitim-ve-ogretmen-16656

Harmandar, M., Bayrakceken, S., Kincal, R. Y., Buyukkasap, E., \& Kizilkaya, S. (2000). Kazim Karabekir Egitim Fakultesinde okul deneyimi uygulamasi ve sonuclarinin degerlendirilmesi. National Education, 148. Retrieved from http://dhgm.meb.gov.tr/yayimlar/dergiler/Milli_Egitim_Dergisi/148/1.htm

Hossain, A., \& Ali, K. (2014). Relation between individual and Society. Open Journal of SocialSciences, 2(8), 130-137. https://doi.org/10.4236/jss.2014.28019

Hudson, P., \& Sempowicz, T. (2011). Analysing mentoring dialogues for developing a preservice teacher's classroom management practices. Australian Journal of TeacherEducation, 36(8), 1-16. https://doi.org/10.14221/ajte.2011v36n8.4

Inceoglu, M. (2010). Tutum algi iletisim. Istanbul: Bilkent University Publishing.

Izadinia, M. (2017). From swan to ugly duckling? Mentoring dynamics and preservice teachers' readiness to teach. Australian Journal of TeacherEducation, 42(7), 66-83. https://doi.org/10.14221/ajte.2017v42n7.5

Kahraman, D. (2014). Ideas and solution proposals of classroom teachers related to the problems during application of visual arts course curriculum. Abant Izzet Baysal University Journal of Faculty of Education, 14(1). https://doi.org/10.17240/aibuefd.2014.14.1-5000091510 
Kani, Z. G., \& Yilmaz, C. (2018). Pre-service EFL teachers' observation-in-action during school experience: Implications for professional development. European Journal of English Language Teaching, 3(4), 114-132. http://doi.org/10.5281/zenodo. 1323158

Kinder, J. S. (1973). Using instructional media. New York: Litton Educational Pub. Inc.

Kirksekiz, A., Uysal, M., Isbulan, O., Akgun, E. O., Kiyici, M., \& Horzum, B. M. (2015). A critical view to school experience and application of teaching courses: Problems, expectations and solution suggestions. Bartin University Journal of Faculty of Education, 4(2), 433-451. https://doi.org/10.14686/buefad.v4i2.1082000250

Lauermann, F. (2013). TeacherResponsibility: It'smeaning, measure and educational implications (Unpublished doctoral dissertation). University of Michigan, Michigan.

Ogan-Bekiroglu, F., Kahveci A., Irez, S., Seker, H., \& Cakir, M. (2010). Evaluation of faculty-school partnership model: Pre-service science teachers' views. Journal of Turkish Science Education, 7(4), 148-168. Retrieved from https://www.tused.org/index.php/tused/article/view/542/467

Okogbaa, V. (2017). Preparing the teacher to meet the challenges of a changing world. Journal of Education and Practice, 8(5), 81-86. Retrieved from https://files.eric.ed.gov/fulltext/EJ1132965.pdf

Paker, T. (2008). Problems of student teachers regarding the feedback of university supervisors and mentors during teaching practice. Pamukkale University Journal of Education, 1(23), 132-139. Retrieved from http://static.dergipark.org.tr:8080/article-download/imported/5000056192/5000053401.pdf

Sag, R. (2007). Öğretmen ĕgitiminde uygulama öğretmenliği uygulamalarının değerlendirilmesi (Unpublished doctoral dissertation). Anadolu University, Eskisehir.

Sevce, S. (2017). İlkokullarda görev yapan sinıf ögretmenlerinin sinıf yönetimi becerilerinin incelenmesi (Unpublished master's thesis). Cukurova University, Adana.

Sonmez, V. (2010). Program geliştirmede ogretmen el kitabı. Ankara: Ani Publishing.

Yilmaz, E., \& Bilici, S. (2016). Visual arts course in instructional technology and material use cases. Ahi Evran University Journal of Kirsehir Education Faculty, 17(1), 343-362. Retrieved from http://kefad2.ahievran.edu.tr/archieve/pdfler/Cilt17Sayi1/JKEF_17_1_2016_343-362.pdf

Yolcu, E. (2004). Sanat eğitimi kuramlari ve yontemleri. Ankara: Nobel Publishing. https://doi.org/10.14527/9786052414835

\section{Note}

Note 1. The present study involves a part of data from the Master's thesis, 'Attitude and approaches of mentor art teachers towards pre-service art teachers during student teaching experience (A sample group from Bursa)', which was completed by Alper Cetin in 2018, under the supervision of Gonca Erim at Uludag University, Faculty of Education.

\section{Copyrights}

Copyright for this article is retained by the author(s), with first publication rights granted to the journal.

This is an open-access article distributed under the terms and conditions of the Creative Commons Attribution license (http://creativecommons.org/licenses/by/4.0/). 